\title{
Microbial Rennet Produced by Mucor miehei in Solid-State and Submerged Fermentation
}

\author{
Guilherme Garcia da Silveira ${ }^{1}$, Gustavo Monteiro de Oliveira $^{1}$, Eloizio Julio Ribeiro ${ }^{2}$ \\ Rubens Monti ${ }^{3}$ and Jonas Contiero ${ }^{1 *}$ \\ ${ }^{I}$ Departamento de Bioquímica e Microbiologia; Universidade Estadual Paulista - Unesp; jconti@rc.unesp.br; Rio \\ Claro - SP - Brasil. ${ }^{2}$ Faculdade de Engenharia Química; Universidade Federal de Uberlândia; Uberlândia - MG - \\ Brasil. ${ }^{3}$ Departamento de Alimentos e Nutrição; Universidade Estadual Paulista - Unesp; Rio Claro - SP - Brasil
}

\begin{abstract}
The aim of this work was to study the effect of carbon and nitrogen sources in submerged fermentation, and the casein effect on solid-state fermentation on rennin production by Mucor miehei. Biomass peaks reached 6.7; 8.1 and $8 \mathrm{~g} / \mathrm{L}$ and enzymatic production peaks of 1,066; 857 and 480 Soxhlet Units (S.U.) for glucose concentration of 18; 25 and $35 \mathrm{~g} / \mathrm{L}$ respectively. Flasks with baffles showed biomass peaks of 6.7; 8.3 and $10 \mathrm{~g} / \mathrm{L}$ and enzyme activity peaks of 648; 279 and 300 S.U. for the same glucose concentration. The values of 923 and 667 S.U. were obtained when corn steep liquor and Proflo (Cottonseed Nutrients from Traders ${ }^{\circledR}$ ) were used. In SSF system the enzymatic activities were 414, 264 and $167 \mathrm{~S}$.U., when using $\mathrm{HCl} 0.2 \mathrm{~N}, 0.3 \mathrm{~N}$ and $0.4 \mathrm{~N}$ respectively. SSF experiments using 1 and $2 \mathrm{~g}$ of casein/gram wheat bran (10\% moisture) showed an increase in the enzymatic production (966 and 1,117 S.U.). The results suggested that increase in glucose concentration affected the enzyme synthesis, and casein was the prime factor in the enzyme synthesis induction. SSF showed to be a good system for rennin production.
\end{abstract}

Key words: Mucor miehei, rennin, clotting activity, casein, solid-state fermentation, submerged fermentation

\section{INTRODUCTION}

Cheese production, as well as the use of exogenous enzymes in their manufacture date back to 6000 B.C (Neelakantan et al., 1999). The rennin acts on the milk protein in two stages, through enzymatic and non-enzymatic action, resulting in the coagulation of the milk. In the enzymatic phase, the milk becomes a gel, due to the calcium ions influence and the temperature used in the process. Calf rennet obtained from the fourth stomach of suckling calves (Nagodawithana and Reed, 1993; Scriban, 1985) is used all over the world to manufacture most of the cheese varieties. The recent growth in the cheese industry and the scarcity on calf rennet have stimulated the research for milk clotting enzyme from alternative sources (Escobar and Barnett, 1993; Fox, 1991). Many microorganisms are known as producers of rennet such as proteinases, which can substitute the calf rennet. Microorganisms like Rhizomucor pusillus, Rhizomucor miehei, Endothia parasitica, Aspergillus oryzae, and Irpex lactis are extensively used for rennet production in cheese manufacture [Bailey and Siika-Aho, 1988; Escobar and Barnett, 1993; Kan et al., 1979; Kolaczkowska et al., 1988; Lasure, 1980; Neelakantan et al., 1999, Thakur et al.1990). The aspartyl protease from Mucor miehei is commonly

\footnotetext{
* Author for correspondence
} 
used as a chymosin substitute in cheese making. This enzyme has a high ratio of MCA/PA (milk clotting activity/proteolytic activity) (Escobar and Barnett, 1995; Thakur et al., 1990), an important requirement to substitute calf rennet. Researchers have investigated the enzyme production by Mucor miehei through submerged fermentation (Bailey and Siika-Aho, 1982; Beyenal et al., 1999 Escobar and Barnett, 1995;Lasure, 1980; Seker et al., 1999; Streets and Ingle, 1972) studying the effects of the medium composition, $\mathrm{pH}$, concentration of each constituent, and operational parameters, such as agitation and dilution rate, temperature on the enzyme production in batch and continuous system. These systems showed that high agitation rate increased the enzyme production (Escobar and Banett, 1993). On the other hand, high glucose concentration inhibited the enzyme production (Beyenal et al., 1999; Seker et al., 1999) and high concentration of amino acids and sulfate repressed the enzyme activity (Lasure, 1980). Enzyme production has also been studied through solid state fermentation (Fernandez-Lahore et al., 1999, Fernandez-Lahore et al., 1998; Pandey et al., 1999; Pandey et al., 2000; Preetha and Boopathy,1994; Thakur et al.,1990; Thakur et al.,1993) verifying the effects of operational parameters such as temperature, influence of the moisture content in solid substrate medium, effect of nutritional parameters. Studies of the medium composition effects on the rennin production have been elucidated mostly in batch submerged fermentation or solid-state systems (Kan et al., 1979; Kolaczkowska, 1988; Lasure, 1980; Thakur et al., 1990). For Mucor miehei, the use of casein in the medium induced high enzyme yields, and the lack of glucose resulted in a significant decrease in the enzyme production. On the other hand, the enzymatic preparation obtained by solid-state fermentation showed a lower proteolytic and lipolytic activity (Arima and Iwasaki, 1970). In this study the fungus Mucor miehei was grown in a submerged fermentation. In these experiments, glucose concentration was modified, and casein concentration was maintained constant. The enzyme production in submerged fermentation was compared with the milk clotting activity obtained in solid-state fermentation where the casein concentration was modified. Solid-state fermentation was also compared when wheat bran was supplemented with casein and pre-treatment with $\mathrm{HCl}$ solution.

\section{MATERIALS AND METHODS}

\section{Microorganism and culture}

Mucor miehei NRRL 3420 was obtained from Fundação André Tosello and maintained on Sabouraud Agar slants at $15^{\circ} \mathrm{C}$. To recover the spores, Roux flasks containing $100 \mathrm{~mL}$ of Sabouraud Agar were inoculated and incubated at $35^{\circ} \mathrm{C}$. After $72 \mathrm{~h}$, the inoculum was obtained by scraping the agar surface in the presence of 200 $\mathrm{mL}$ sterile water. The spore suspension $\left(10^{6}\right.$ spores $/ \mathrm{mL}$, determinated by Neubauer Chamber) was transferred to 500 (SLF) and 250 (SSF) $\mathrm{mL}$ erlenmeyer flasks containing sterilized $\left(121^{\circ} \mathrm{C} / 20\right.$ min.) growth medium.

\section{Culture media}

\section{Submerged liquid fermentation medium}

The composition of growth medium was $(\mathrm{g} / \mathrm{L})$ : glucose (18, 25 and 35); peptone (8); casein (8); $\mathrm{KH}_{2} \mathrm{PO}_{4}$ (2); corn steep liquor [CSL] $(1.1 ; 2.2$; 4.4; 8.8 and 17.6) and Proflo [Cottonseed Nutrients from Traders $\left.{ }^{\circledR}\right]$ (4 and 8). The initial pH was 6.0.

\section{Solid-state fermentation medium}

The composition of growth medium was $(\mathrm{g} / \mathrm{g}$ wheat bran): wheat bran (10); casein $(0.5,1.0,1.5$, 2.0, 3.0, 5.0 and 10.0) plus ten milliliters of water or ten milliliters of $\mathrm{HCl} 0.2 \mathrm{~N} ; 0.3 \mathrm{~N}$ or $0.4 \mathrm{~N}$ per 10 grams wheat bran. The initial moisture of wheat bran was $10 \%$.

\section{Culture Conditions}

\section{Submerged liquid fermentation (SLF)}

Erlenmeyer flasks $(500 \mathrm{~mL})$ and baffled flasks (Erlenmeyers with four baffles) containing $90 \mathrm{~mL}$ of medium (sterilized at $121{ }^{\circ} \mathrm{C}$ for $15 \mathrm{~min}$.) were inoculated with a spore suspension $(10 \% \mathrm{v} / \mathrm{v})$ prepared from Mucor miehei Roux culture $\left(10^{6}\right.$ spores $/ \mathrm{mL})$. The flasks were incubated in orbital shaker (News Brunswick) at $35^{\circ} \mathrm{C}$ and $150 \mathrm{rpm}$. The initial $\mathrm{pH}$ was 6.0. Submerged Fermentation was also carried out in reactor of 5 liters with working volume of 2 liters and temperature (35 ${ }^{\circ} \mathrm{C}$, agitation (380 rev. $\left.\mathrm{min}^{-1}\right)$, aeration $(2 \mathrm{vvm})$ and $\mathrm{pH}$ (6.0) controlled. The inoculum $\left(10^{6}\right.$ spores $/ \mathrm{mL})$ of reactor medium was $10 \%(\mathrm{v} / \mathrm{v})$. 


\section{Solid-state fermentation (SSF)}

Erlenmeyer flasks $(250 \mathrm{~mL})$ containing $10 \mathrm{~g}$ of wheat bran plus a range of casein concentration (sterilized at $121^{\circ} \mathrm{C}$ by $15 \mathrm{~min}$.) were inoculated with $10.0 \mathrm{~mL}$ of spore solution $\left(10^{6}\right.$ spores $\left./ \mathrm{mL}\right)$ and incubated at $35^{\circ} \mathrm{C}$ under static condition for 72 h. $250 \mathrm{~mL}$ Erlenmeyer flasks containing $10 \mathrm{~g}$ of wheat bran were moistened with $10 \mathrm{~mL}$ of 0.2 , 0.3 and $0.4 \mathrm{~N} \mathrm{HCl}$ solutions and sterilized at $121^{\circ} \mathrm{C}$ for 15 minutes. The medium was inoculated with $10^{6}$ spore / g wheat bran.

\section{Enzyme extraction in submerged liquid} fermentation and solid-state fermentation

The samples were taken each $24 \mathrm{~h}$ of cultivation and separated from the mycelium through a Filtrak $\mathrm{GmbH}$ paper filter $(\varnothing 90 \mathrm{~mm})$. After centrifugation $(5,000 \mathrm{~g})$ the filtrate was used for enzyme assay. The enzyme recovery in solid-state fermentation was obtained by adding $100 \mathrm{~mL}$ of cold sterile water (Fernandez-Lahore, 1998). The mycelium and solid medium were separated by cotton filtration, and the filtrate was centrifuged and used for enzyme assay.

\section{Enzyme activity}

Milk-clotting activity (MCA) was determined according to the method of Arima and Iwasaki, (1970) and expressed in terms of Soxhlet Unit.

\section{Biomass measure}

For biomass determination, samples of the culture fluid $(30 \mathrm{~mL})$ were filtered through dried paper filters [Filtrak $\mathrm{GmbH}$ paper filter $(\varnothing 90$ $\mathrm{mm})$ ], and mycelial dry-mass was determined after drying at $80^{\circ} \mathrm{C}$ for $24 \mathrm{~h}$.

\section{Sugar determination}

Total reducing sugars were determinated as a glucose according methods of Miller (1959).

\section{RESULTS AND DISCUSSION}

Table 1 showed optimum glucose concentration (over $18 \mathrm{~g} / \mathrm{L}$ ) on the enzyme synthesis, showing that an inhibition by substrate occurred.

Table 1 - Microbial rennin production through SLF in flasks with/without baffles after 120 hours fermentation, temperature $35^{\circ} \mathrm{C}, 150 \mathrm{rpm}$.

\begin{tabular}{|c|c|c|}
\hline Flasks type & Glucose concentration $(\mathrm{g} / \mathrm{L})$ & Highest clotting activity (S.U.) \\
\hline \multirow{5}{*}{ 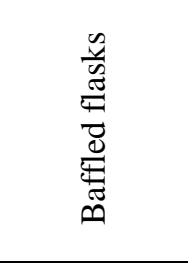 } & 0 & 0 \\
\hline & 9 & 58 \\
\hline & 18 & 648 \\
\hline & 25 & 279 \\
\hline & 35 & 300 \\
\hline \multirow{5}{*}{ 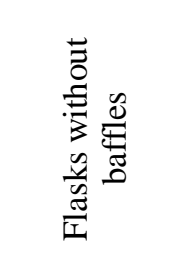 } & 0 & 0 \\
\hline & 9 & 81 \\
\hline & 18 & 1066 \\
\hline & 25 & 857.4 \\
\hline & 35 & 357 \\
\hline
\end{tabular}

Beyenal et al. (1999); Seker et al.(1999), Silveira and Contiero (2001) also observed this fact. The use of baffled flasks permited more aeration with an increased in the growth and a decrease in the enzyme production. Experiments with sucrose as main carbon source, carried out in reactor with $\mathrm{pH}$ control, showed poor enzyme production $(<168.0$ S.U.). It must be evident the effort of microorganism to hydrolyze this carbon source to obtain the glucose to induce the enzyme synthesis. Similar fact occurred when using molasses as main carbon source, where the maximum activity was 250 S.U. (Total Reducing Sugars concentration $18 \mathrm{~g} / \mathrm{L}$ ). Table 2 shows the influence of casein concentration and Proflo on the rennin production. High levels of free amino 
acids (1\%) appeared to repress enzyme activity, as observed by Lasure (1980). The high activity, 666.7 S.U., was reached when the initial concentration of both, casein and Proflo were 4 $\mathrm{g} / \mathrm{L}$, where the low nitrogen concentration and low $\mathrm{pH}$ have a positive contribution for the production and the enzymatic stability. The use of $8 \mathrm{~g} / \mathrm{L}$ of Proflo in the medium resulted lower activity (270.3 S.U.), and high biomass production, showing a probable metabolic deviation for biomass synthesis in the metabolism. Seker et al. (1999) observed this using high carbon concentration. The usage of low Proflo concentration and casein showed to be useful for the enzyme production. Experiments were also carried out to study the effect of corn steep liquor in the medium as a nitrogen source for rennin production (Table 3 ).

Table 2 - Rennin production at 96 hour by SLF using Mucor miehei at several Proflo and casein concentrations.

\begin{tabular}{c|c|c|c|c}
\hline Nitrogen Source & Glucose concentration (g/L) & $\begin{array}{c}\text { Highest Clotting activity } \\
\text { (S.U.) }\end{array}$ & Biomass (g/L) & $\mathbf{p H}$ \\
\hline $\begin{array}{c}\text { Proflo } \\
4 \mathrm{~g} / \mathrm{L}\end{array}$ & 18 & 585.4 & 9.6 & 7.5 \\
$\begin{array}{c}\text { Proflo } \\
8 \mathrm{~g} / \mathrm{L}\end{array}$ & 18 & 270.3 & 10.6 & 7.4 \\
$\begin{array}{c}\text { Proflo } \\
\text { g/L + Casein } \\
4 \mathrm{~g} / \mathrm{L}\end{array}$ & 18 & & & \\
\hline
\end{tabular}

Table 3 showed the highest enzymatic activity (923 S.U.) was obtained when $2.2 \mathrm{~g}$ corn steep liquor/L was used in the medium. There was a decrease in the enzyme production when the concentration increased. The increase in corn steep liquor concentration was followed by an increase in biomass concentration. A decrease in the enzymatic activity also observed at concentrations around and below $1.1 \mathrm{~g}$ corn steep liquor/L.

Table 3 - Maximum clotting activity, at 96 hour by SLF in several corn steep liquor concentrations.

\begin{tabular}{c|c|c}
\hline CSL concentration $(\mathbf{g} / \mathbf{L})$ & Highest Clotting activity $(\mathbf{S . U .})$ & Biomass $(\mathbf{g} / \mathbf{L})$ \\
\hline 1.1 & 685.7 & 6.3 \\
2.2 & 923 & 6.4 \\
4.4 & 705.9 & 5.3 \\
8.7 & 500 & 7.1 \\
17.5 & 171.4 & 8.0 \\
\hline
\end{tabular}

Fermentations using sucrose and molasses as carbon source

Flasks experiments using molasses and sucrose for enzyme production showed a $\mathrm{pH}$ increase during the fermentation. High $\mathrm{pH}$ affects the enzyme stability. Experiments with molasses and sucrose in medium composition carried out in reactors (5 liters), $\mathrm{pH}(6.0)$, aeration (2 vvm) and agitation $(380 \mathrm{rpm})$ did not reach high rennin production. Both, sucrose and molasses were not considered as good carbon sources. The results of the enzymatic activity were 138 S.U. for sucrose at $25 \mathrm{~g} / \mathrm{L}$ and $233 \mathrm{~S} . \mathrm{U}$. for molasses at $35 \mathrm{~g} / \mathrm{L}$ total reducing sugars.

Enzyme production by solid-state fermentation Table 4 shows the behavior of the microorganism related to the medium composition. Highest enzymatic activity occurred at $48 \mathrm{~h}$ of cultivation. Figure 1 showed the milk clotting activity until 72 $h$, where the enzyme activity was better when the medium was supplemented with 2 grams of casein and with $0.3 \mathrm{~N} \mathrm{HCl}$ the enzyme activity increased after $48 \mathrm{~h}$ of fermentation. 


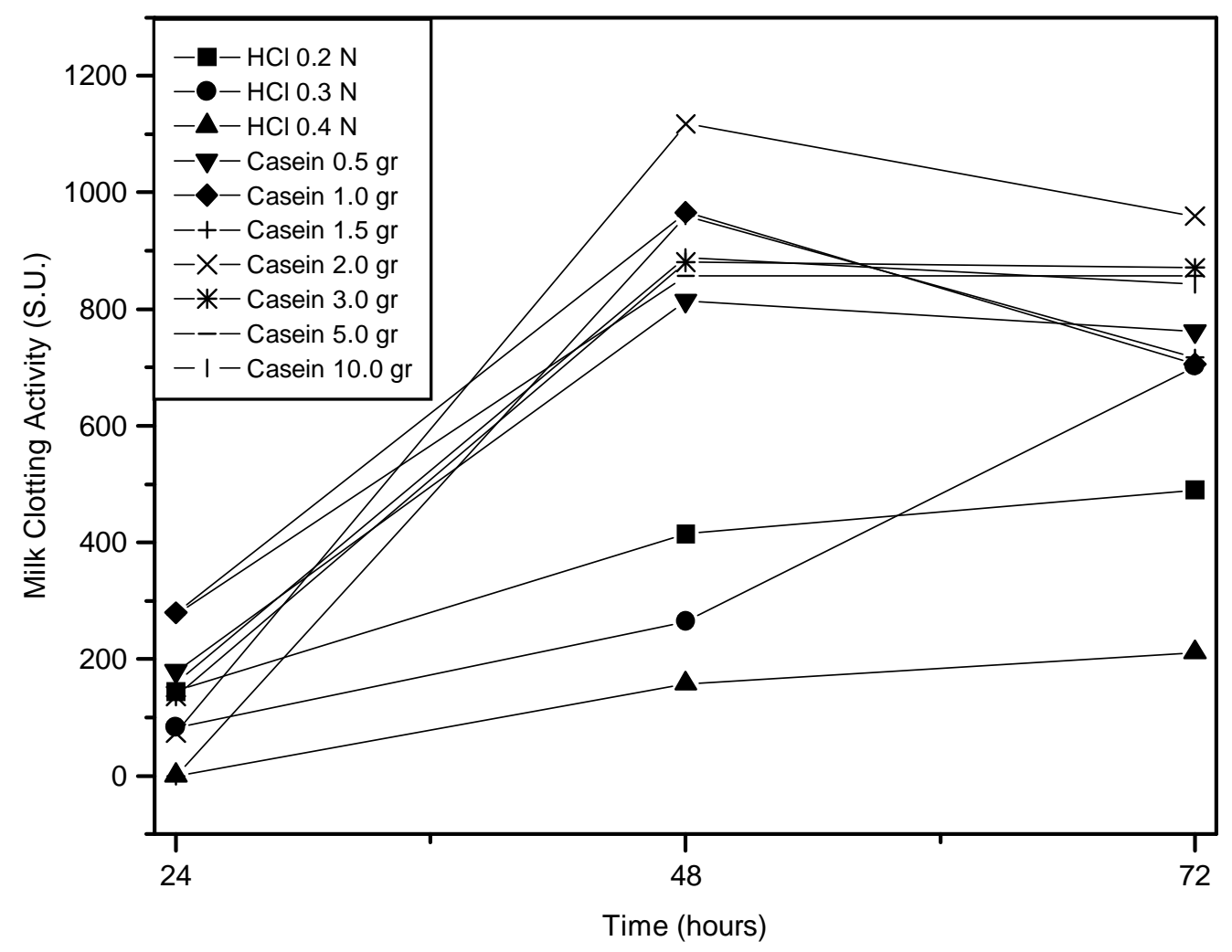

Figure 1 - Milk clotting activity for Mucor miehei on SSF fermentation during $72 \mathrm{~h}$ and $35^{\circ} \mathrm{C}$.

Table 4 - Maximum rennin production by Mucor miehei during 48 hours of cultivation on wheat bran added with $\underline{\mathrm{HCl}}$ and casein concentrations at $35^{\circ} \mathrm{C}$.

\begin{tabular}{c|c|c|c}
\hline$*$ & Initial $\mathbf{~ H}$ & Final $\mathbf{~ H}$ & Clotting activity (S.U.) \\
\hline $\mathrm{HCl} 0.4 \mathrm{~N}$ & 4.0 & 4.02 & 157.0 \\
$\mathrm{HCl} 0.3 \mathrm{~N}$ & 4.5 & 5.12 & 264.0 \\
$\mathrm{HCl} 0.2 \mathrm{~N}$ & 5.3 & 6.27 & 414.0 \\
0.5 gram of & 6.00 & 6.84 & 813.6 \\
$\quad$ Casein & 5.57 & 7.1 & 966.0 \\
1.0 gram of & 5.35 & 6.88 & 960.0 \\
$\quad$ Casein \\
$\begin{array}{c}1.5 \text { grams of } \\
\text { Casein }\end{array}$ & 5.25 & 7.02 & $1,117.0$ \\
$\begin{array}{c}\text { 2.0 grams of } \\
\text { Casein }\end{array}$ & 5.06 & 7.64 & 880.8 \\
3.0 grams of \\
$\quad$ Casein \\
$\begin{array}{c}\text { 5.0 grams of } \\
\text { Casein }\end{array}$ & 4.82 & 7.65 & 857.1 \\
10 grams of & 4.51 & 7.77 & 888.9 \\
Casein & &
\end{tabular}


These results when compared to Preetha and Boopaathy (1994) and Thakur et al. (1990) showed a time decreased on enzyme production. When $\mathrm{HCl}$ at $0.4 \mathrm{~N}$ was used, the activity was 157 S.U. while at $0.2 \mathrm{~N}$ and $0.3 \mathrm{~N}$ it was 414 and 264 S.U. respectively, showing that a possible catabolic repression occurred because of the free carbohydrate from wheat bran hydrolysis (Thakur et al., 1990). In these experiments the highest activity occurred after $72 \mathrm{~h}$ of fermentation. Table 4 showed that casein was an important factor in the enzyme production. This could be observed from rise on casein concentration, which resulted increase in coagulant activity. Between 1 and 2 gr of casein, the high enzymatic production was reached $(1,117$ S.U.) during $48 \mathrm{~h}$ of fermentation; this value is close to the submerged fermentation; however, over $2 \mathrm{~g}$ of casein a decreased in enzyme production was observed, probably because of catabolic repression. Preetha and Boopathy (1994) studied the influence of the powder skim milk inclusion in solid medium and observed that concentrations over $2 \%$ of this resulted an increase of 3.5 times in the coagulant activity related to the control. Thakur et al. (1990) observed that the higher coagulant activity was obtained using $5.0 \%$ of powder skim milk. Casein is the constituent in most expressive quantities in powder skim milk, thus proving the role in the induction of the enzyme synthesis.

\section{CONCLUSION}

In this study can observed that the solid-state fermentation was a good method for rennin enzyme production. The results were closed to submerged fermentation when supplemented with casein, which showed that casein had an important role in rennin production. The use of corn steep liquor instead of peptone showed to be a better nitrogen source for enzyme production in submerged fermentation. Sucrose and molasses did not show to be good carbon sources for enzyme production.

\section{ACKNOWLEDGEMENTS}

This work was financially supported by FAPESP and CNPq. We thank São Paulo State University (UNESP) for their technical support.

\section{RESUMO}

A produção de renina microbiana por Mucor miehei foi estudada através de Fermentação Submersa e em Estado Sólido. O objetivo deste trabalho foi verificar o efeito de diferentes fontes de carbono e nitrogênio, utilizando Fermentação Submersa e da adição de caseína utilizando Fermentação em Estado Sólido na produção da renina microbiana. Os picos de biomassa foram de 6,$7 ; 8,1$ e $8 \mathrm{~g} / \mathrm{L}$ e atividade enzimática de 1.066 ; 857 e 480 Unidades Soxhlet (U.S.) para as concentrações de glicose: 18,25 e 35 g/L respectivamente. Em frascos aletados, os picos de biomassa foram de 6,$7 ; 8,3$ e $10 \mathrm{~g} / \mathrm{L}$ e atividade enzimática de 648, 279 e 300 U.S., para a mesma concentração de glicose. Quando se utilizou Proflo (Farinha de semente de algodão, Traders ( $)$ ) e Água de Maceração de Milho os picos de atividade enzimática foram de 667 e 923 U.S., respectivamente. Nos experimentos utilizando Fermentação em Estado Sólido com a adição de $\mathrm{HCl} 0,2 \mathrm{~N}$ a máxima atividade enzimática foi de 414 U.S. e, quando utilizou-se caseína (1 e 2 gramas), verificou-se valores mais altos de atividade: 966 e 1117 U.S respectivamente. Os resultados sugerem que o aumento na concentração de glicose afeta a síntese da enzima e que a caseína é um importante fator na indução neste processo. Fermentação em Estado Sólido pode ser considerada uma boa opção para a produção de renina.

\section{REFERENCES}

Arima, K.; Yu, J. and Iwasaki, S. (1970), Milk-clotting enzyme from Mucor pussilus var. Lindt. Methods in Enzymology, 19, 446-460.

Bailey, M. J. and Siika-Aho, M. (1988), Production of microbial rennin. Biotechnology Letters, 10, 161-166.

BeyenaL, H.; Seker, S.; Salih, B. and Tanyolaç, A. (1999), The effect of D-glucose on milk clotting activity of Mucor miehei in a chemostat with biomass retention. Journal of Chemical Technology and Biotechnology, 74, 527-532.

Escobar, J. and Barnett, S. (1993), Effect of agitation speed on the synthesis of Mucor miehei acid protease. Enzyme Microb. Technol., 15, 1009-1013.

Escobar, J. and Barnett, S. (1995), Syntesis of Acid Protease from Mucor miehei: Integration of Production and Recovery. Process Bioch., 30, 695-700. 
Fernandez-Lahore, H. M.; Auday, R. M.; Fraile, E. R.; Biscoglio de Jimenes Bonino, M.; Pirpignani L.; Machalinski, C. and Cascone, O. (1999), Purification and characterization of na acid protease from mesophilic Mucor sp. Solid-state cultures. The Journal of Peptide Research, 53, 599-605.

Fernandez-Lahore, H. M.; Fraile, E. R. and Cascone, O. (1998), Acid protease recovery from a solid-state fermentation system. Journal of Biotecnology, 62, 83-93.

Fox, P. F. (1991), Food Enzymology. New York, London: Elsevier Science Publisher.

Kan, M. R.; Blain, J. A. and Patterson, D. E. (1979), Extracellular proteases of Mucor pisullus. Applied Environmental Microbiology, 37, 719-724.

Kolaczkowska, M.; Chrzanowska, J.; Jacyk, A.; Szolrysek, K. and Polnowski, A. (1988), Factors affecting rennin-like proteinase production by Fusarium moniliforme. Milchwissenschaft, 43, 83-86.

Lasure, L. L. (1980), Regulation of extracellular acid protease in Mucor miehei. Mycol., 72, 483-493.

Miller, G. L. (1959), Use de dinitrosalicylic acid reagent for determination of reducing sugars. Analytical Chemistry, 31, 426-428.

Nagodawithana, T. and Reed, G. (1993), Enzymes in Food Processing. $3^{\text {nd }}$ ed. San Diego: Academic.

Neelakantan, S.; Mohanty, A. K. and Kaushik, J. K. (1999), Production and use of microbial enzymes for dairy processing. Current Science, 77, 143-148.

Pandey, A.; Selvakumar, P.; Soccol, C. R. and Nigam, P. (1999), Solid State Fermentation for the production of industrial enzymes. Current Science, 77, 149-162.

Pandey, A.; Soccol, C. R. and Mitchell, D. (2000), New developments in solid fermentation: I-bioprocess and products. Process Biochemistry, 35, 1153-1169.
Preetha; S. and Boopathy, R. (1994), Influence of culture conditions on the production of milk clotting enzyme from Rhizomucor. World Journal of Microbiology and Biotechnology, 10, 527-530.

Scriban, R. (1985), Biotecnologia. São Paulo: Manole Ltda.

Seker, S.; Beyenal, H. and Taniolaç, A. (1999), Modeling Milk Cotting Activity in the Continuous Production of Microbial Rennet from Mucor miehei. Journal of Food Science, 64, 525-529.

Silveira, G. G. and Contiero, J. (2001), Production of microbial rennin from Mucor miehei in batch fermentation. European Journal of Pharmaceutical Sciences, 13, S38.

Streets, B. W. and Ingle, M. B. (1972), The effect of temperature on spore germination and growth of Mucor miehei in submerged culture. Canadian Journal of Microbiology, 18, 975-979.

Thakur, M. S.; Karanth, N. G. and Nand, K. (1990), Production of fungal rennet by Mucor miehei using solid state fermentation. Applied Microbiology and Biotechnology, 32, 409-413.

Thakur, M. S.; Karanth, N. G. and Nand, K. (1993), Downstream processing of microbial rennet from solid state fermented moldy bran. Biotechnology Advances, 11, 399-40. 